\title{
THE ASSESSMENT OF ORGANIZATIONAL BEHAVIOR EFFECTIVENESS ON THE BASIS OF EXPERIMENTAL RESEARCH
}

\author{
Dr. Tamar Vanishvili \\ David Aghmashenebeli National Defense Academy of Georgia
}

\begin{abstract}
Currently ongoing global social and economic events in the modern world are relevant to the organizational behavior of enterprises. Many people view organizational changes as a threat to the existing order. Hence, fear related to changes becomes comprehensible, and considering the fact that any circumstances in the modern dynamic world are changing rapidly, organizational changes consequently become inevitable. A great variety of acknowledged motivational theories comprise employers' interests and their organic involvement in management process. However, many important issues, especially the return of personnel reward, are left without a thorough study and require proper improvement. The object of the research is the assessment of organizational behavior effectiveness on the basis of experimental research. In order to carry out a comprehensive study of this issue, a survey was conducted at Kula and Agrocom, two factories in Gori, Georgia.
\end{abstract}

Keywords: effectiveness indicator of organizational behavior, evaluation criterion, parameter, coefficient, motivation, stimulation, effectiveness, qualification, component.

\section{Introduction}

For Georgia, as a developing country, it is important to thoroughly study various organizational systems established in the economies of developed countries and outline the most efficient components. Numerous examples of organizational management, organizational behavior and proven effective practices of work organization are established in the developed countries with outlined main directions. The ongoing political, economic and social changes in Georgia create a new understanding of the organizational behavior issues primarily pointing to the employment problems.

Georgia belongs to the developing countries and is in the transitional stage of growth. The country is distinguished by job deficiency leading to the low level of employment. Consequently, the country should accept all the instigated changes and withstand their results. It is commonly known that scientific and technological 
progress is based on such variables wherein managers are able to perform their function, i.e. to implement organizational changes and withstand the obstacles as the differences of national cultures can make great impact on the organizational efficiency.

The problem of the research. Scientifically recognized modern theories of motivation consider the interests of staff and its involvement in goal establishment and implementation process in management. It is not implemented using top-down approach, i.e. vertically, but horizontally, i.e. in hierarchies and groups. Typically, a manager cautiously chooses the course of action not for personal reasons but considering the entire organization as the decision influences everybody. The research revealed the situation in the factories and showed that the introduction of new innovations in organizational behavior is sagacious as novelties stimulate new requirements and thus sharpen interests. It is conceivable that certain dogmas and mechanisms in management have been effective for many years; however, it is necessary to change them periodically to partially different and more sophisticated new truths that give a possibility to improve efficient functioning of an organization.

The purpose of the research was to apply an appropriate complex model for the improvement and efficient functioning of the factories (see Figure 1).

The methods of the research, such as mathematical formula, were developed to analyze the obtained results. The effectiveness of organizational behavior (E) was calculated; estimation criterion of the effectiveness indicator of the organizational behavior was determined; the components included in the formula were calculated to summarize the specific shares with the indicator conventionally named $K$ coefficient; complex model of improvement and efficient functioning of the factories was created on the basis of conducted studies.

The object of the research was the assessment of the organizational behavior effectiveness on the basis of experimental research.

A complex model for improvement and efficient functioning of an organization was designed to conduct the research (see Figure 1). 


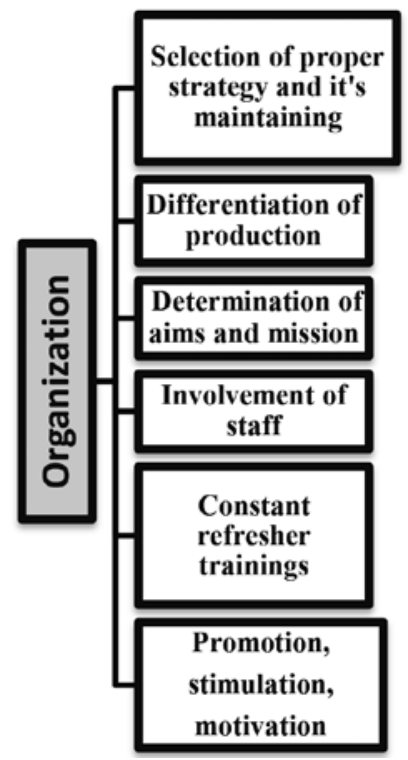

Figure 1. Complex model of perfection and efficient functioning of an organization

The model shows that staff involvement, stipulation of job sites, constant training and refresher training are of ultimate importance. Moreover, the implementation of promotion and personnel reward are obligatory, too. Although motivational theories show that only materialistic motivation and stimulation do not always guarantee the growth of labor productivity, materialistic remuneration allows employees to satisfy some of their needs.

To strengthen the above mentioned considerations and to establish an organization's priorities to improve efficient functioning, a survey was conducted in two factories Kula and Agrocom.

The formula for calculating the efficiency of organizational behavior was created to calculate the efficiency of the organizational behavior indicator E. For this purpose, the following key components were applied:

- Conformity (work, qualification) (C)

- Satisfaction (job involvement) (S)

- Financial Stimulus (FS)

- Faith (F)

The formula for calculating the efficiency of organizational behavior is as follows:

$$
E=(C+S+F S+F): 4
$$


The following criteria were developed to assess the efficiency of organizational behavior that determines the accuracy of this indicator:

Up to $30 \%$ - ineffective

$31 \%-50 \%$ - low

$51 \%-70 \%$ - medium

$71 \%-90 \%$ - good

$91 \%-100 \%$ - very good

Calculation of the enterprises' efficiency:

a) Kula: $\mathrm{E}=(63 \%+85 \%+40 \%+90 \%): 4=69.5 \% \approx 70 \%$; (good)

b) Agrocom: $\mathrm{E}=(45 \%+82 \%+100 \%+100 \%): 4=81.7 \% \approx 82 \%$; (good) (see Diagram 1)

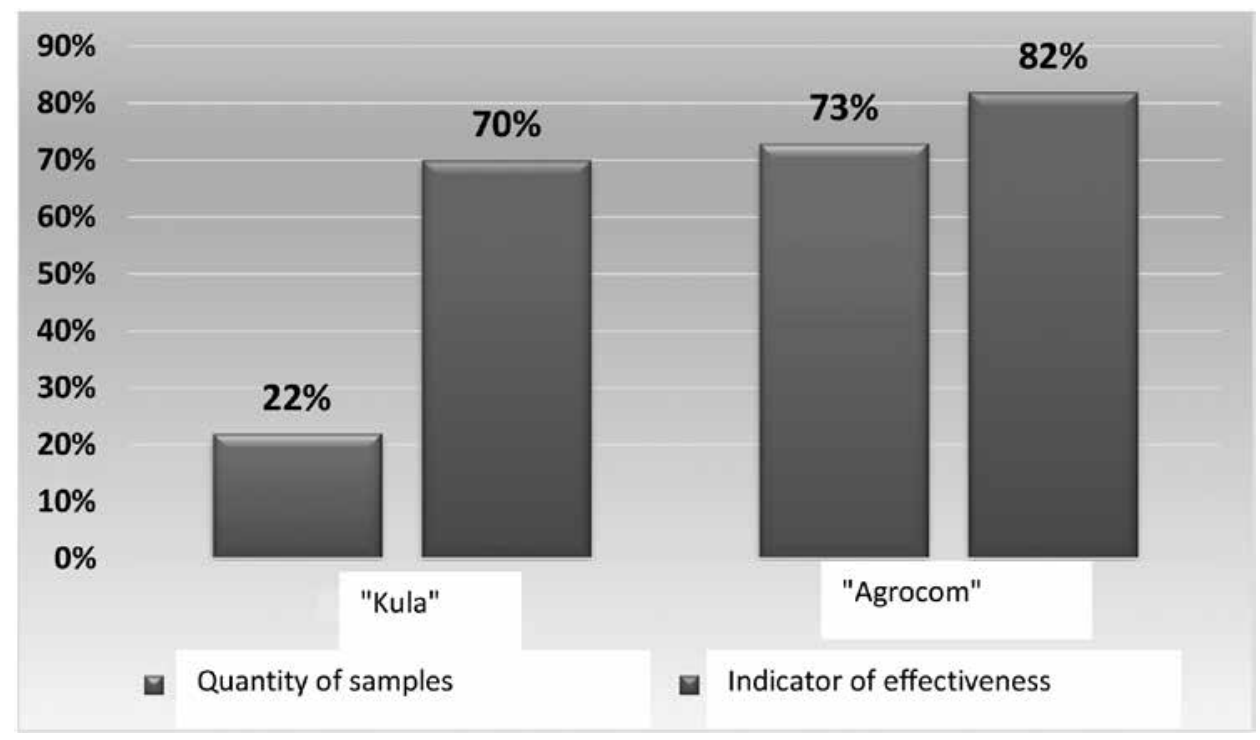

Diagram 1. Comparative parameters of the survey conducted at Kula and Agrocom

Diagram 1 presents the compliance of the surveys conducted at Kula and Agrocom with the indicators of organizational behavior effectiveness.

For both enterprises, the percentage of the components included in the formula for calculating the effectiveness of organizational behavior was applied. Also, the diagrams were drawn for the summation of the components calculated the share including all the components of the formula; this indicator is conventionally called $K$ coefficient which promotes the efficiency of the adjustment of organizational behavior effectiveness indicator (see Diagrams 2, 3, 4, 5):

\section{a) Kula:}

1. Compliance - $63 \%$

2. Satisfaction $-85 \%$

3. Financial Stimulus - $40 \%$ 
4. Faith $-90 \%$

$$
\sum=278
$$

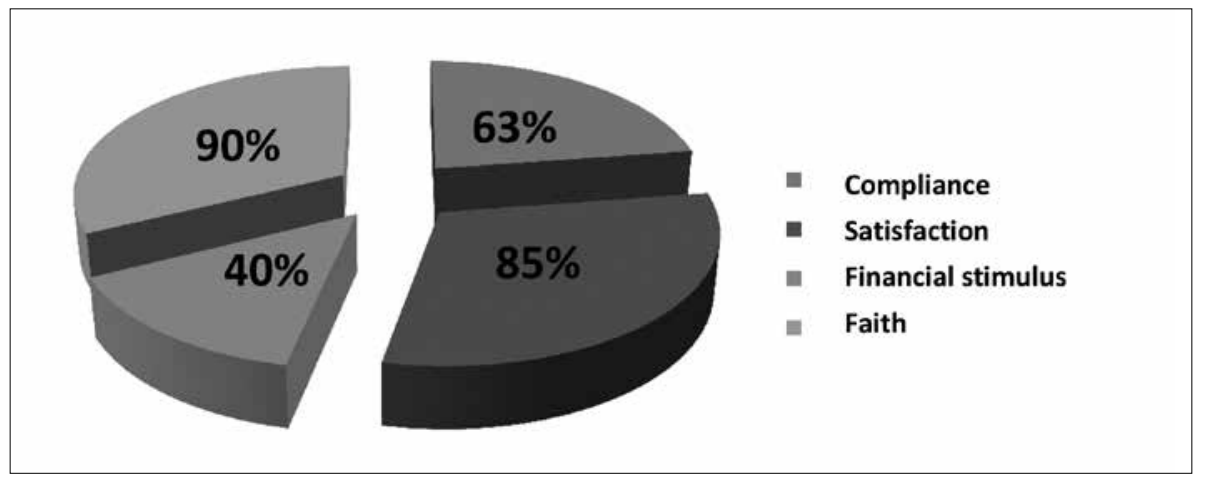

Diagram 2. Components included in the efficiency of organizational behavior of Kula, in percent

\section{$K$ coefficient}

1. The share of compliance $-K=0.23$

2. The share of satisfaction $-\mathrm{K}=0.31$

3. The share of financial stimulus $-\mathrm{K}=0.14$

4. The share of faith $-\mathrm{K}=0.32$.

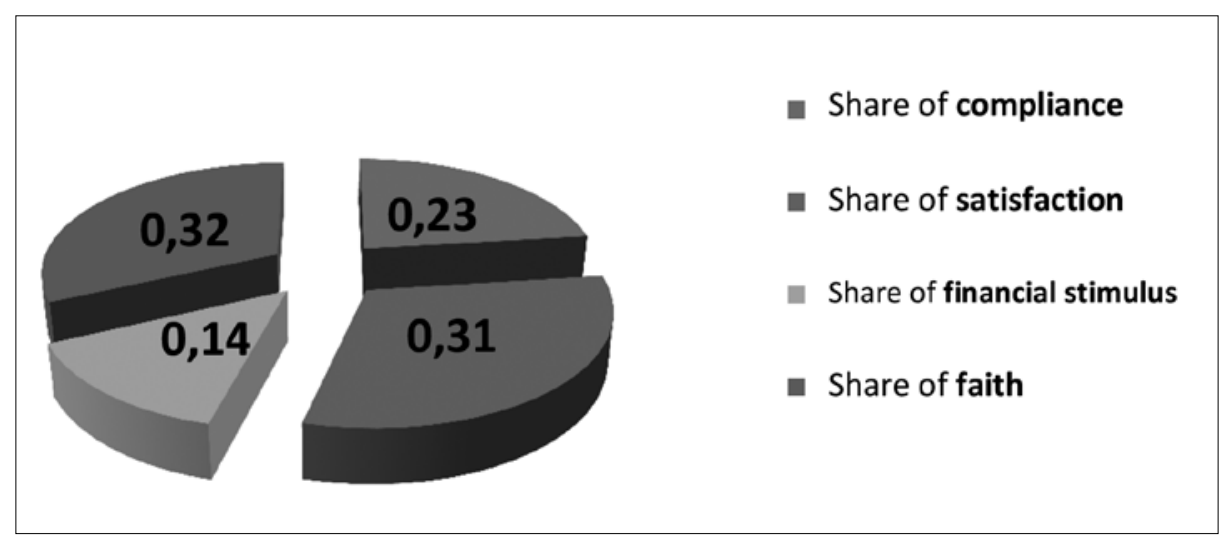

Diagram 3. The share included in the Kula factory's organizational behavior with effectiveness components - $\mathrm{K}$

Diagram 3 illustrates that only financial motivation of the employers does not guarantee satisfaction, because the component of its share is much lower than the other components. In fact, the enterprise may be advised to increase financial stimulus to increase the percentage of financial stimulus which in compliance will lead to the increase of the component of its share; subsequently, it will increase the 
indicator $\mathrm{E}$ of the organizational behavior effectiveness.

b) Agrocom

1. Compliance - $45 \%$

2. Satisfaction $-82 \%$

3. Financial Stimulus - $100 \%$

4. Faith $-100 \%$

\section{$\sum=\mathbf{3 2 7}$}

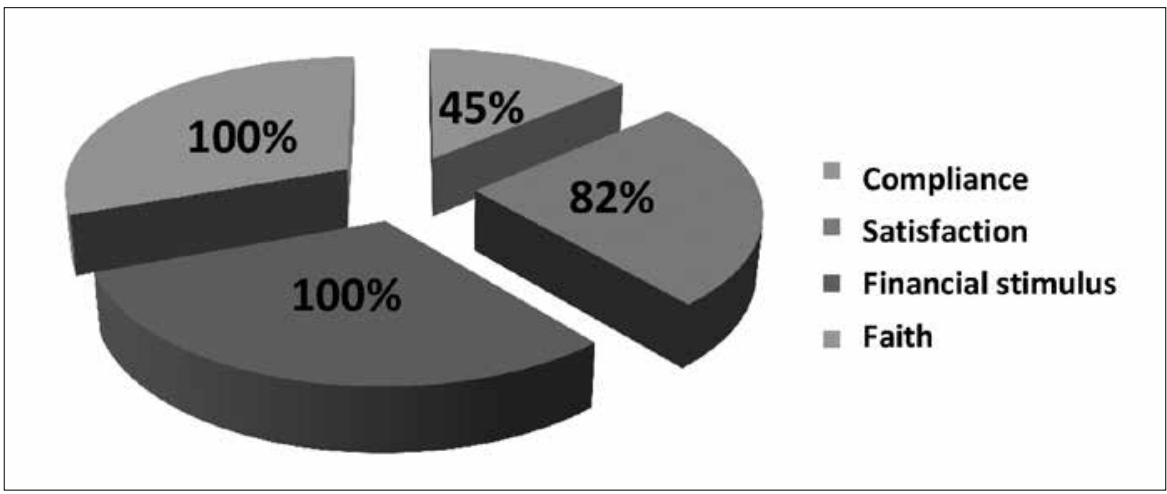

Diagram 4. Components included in the efficiency of organizational behavior of Agrocom, in percent

\section{K coefficient}

1. Share of compliance $-\mathrm{K}=0.13$

2. Share of satisfaction $-K=0.25$

3. Share of financial stimulus $-\mathrm{K}=0.30$

4. Share of faith - $K=0.30$

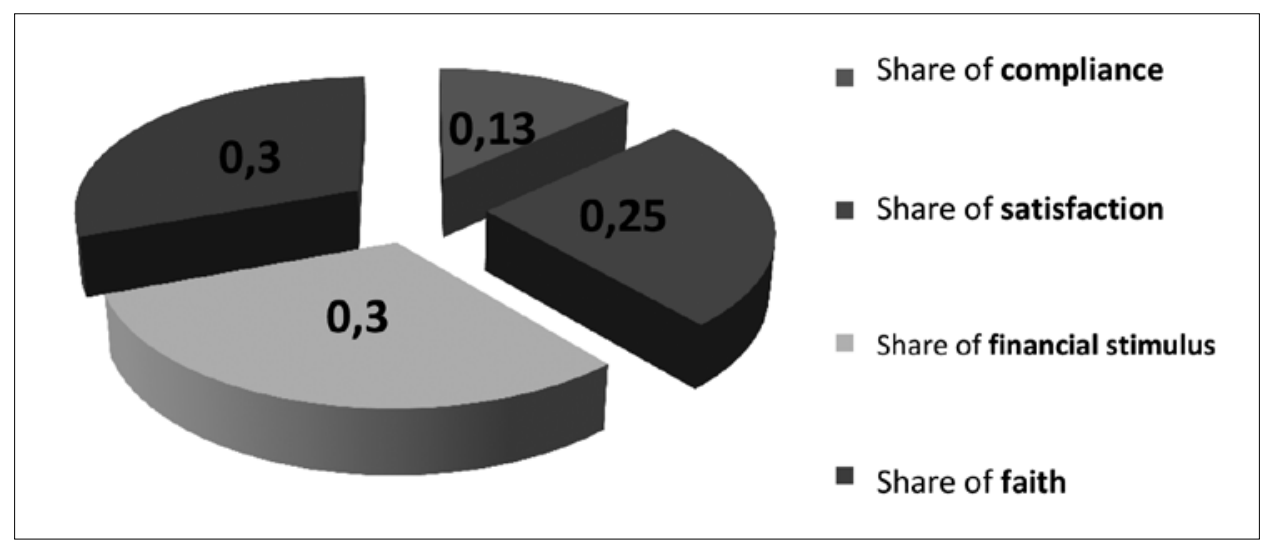

Diagram 5. The share included in the Agrocom factory's organizational behavior effectiveness components - K 
In this case, it can be perceived that the faith factor and financial stimulus indicators are outlined with the highest coefficient for the improvement of the enterprise effectiveness. On improvement, these components do not work, nevertheless, the compliance of qualifications with the existing job and the job satisfaction rate is very low. Subsequently, it means that these enterprises should be recommended to take care of the agreement between the employees' qualification and job. It is obvious that when the employees' qualifications go in line with the performed work, motivation increases equivalently to the enterprise efficiency indicator.

The survey carried out in two factories, included in the research surveys, were experimental, simultaneous with the effectiveness and positive results of the formula which were tested; the efficiency of organizational behavior and the indicator of organizational behavior effectiveness were calculated, the value of this indicator was measured; the $\mathrm{K}$ coefficient was calculated.

It should be noted that in terms of application, all the methods and stages of the research were developed by the researchers themselves and were accepted by an arbitrary organization.

\section{Conclusions and Recommendations}

The modern civilized world offers a necessity of making frequent changes. The arbitrary change makes a positive and negative influence on an organization and organizational behavior. It changes the balance of forces and ongoing processes in the organization. It is noteworthy how we can see positive effects that we have seen in the idea of changes. Also, it is noteworthy that other changes will follow. Some of them may be very damaging to the organization; therefore, it is necessary to make changes more seriously, reveal them and choose the right path for better results.

The study gave us an opportunity to use the classical and modern theories of motivation in practice, their complexity as well as clarity. In fact, it is possible for an enterprise to develop a model that is useful for the content of motivation and does not present practical use, because the modern approach is essential for the enterprise; it is oriented to the interests of employers, stimulation and motivation. Effective fulfilment of tasks gives an enterprise the best results of its activity.

If the skills and abilities of the employees are relevant, an organization will not face worsening, and if tomorrow is like today, organizational changes will be important for managers. Actually, the world is changing and requires dynamical changes to maintain the specificity of an organization and its members.

Our life will be better only if we change ourselves for the better. It does not matter where we start, it is important is where we go. We can consider the past as an experience and change the future for the better. 


\section{References}

1. http://www.bigsale.ge/Agrocom/.

2. http://kula.ge/.

3. Vanishvili T. A. Formation of Modern Model of Management and Regulation Principles of Organizational Behavior (Monograph). Publishing House Technical University, Tbilisi, 2017, - 209 p. (In Georgian).

4. Vanishvili T. A. Innovations and Its Influence on Organizational Structures on Example of "AGROCOM". 7th International Scientific Conference Education and Sustainable Development. Gori State Educational University, 28-29 November 2014, Georgia. Transactions, pp. 231-234. (In Georgian).

5. Vanishvili T. A. Indicator of Effectiveness of Organizational Behavior and Ways of Perfection. Journal Business-Engineering No. 1, Tbilisi, 2015, pp. 165-168.

6. Shengelis T. Fundamentals of Business Administration. Tbilisi, 2008.

7. Lortkipanidze R. Theory of Rational Competitiveness for Limited Efficiency of Management. Tbilisi, 2014. 


\title{
ORGANIZACIJOS ELGESIO EFEKTYVUMO VERTINIMAS TAIKANT EKSPERIMENTINI TYRIMĄ ORGANIZACIJOJE
}

\author{
Dr. Tamar Vanishvili \\ Gruzijos Davido Aghmashenebeli nacionalinè gynybos akademija
}

\section{Santrauka}

Gruzijai, kaip besivystančiai šaliai, yra svarbu nuodugniai ištirti, kaip ịvairiose pasaulinėse organizacijose funkcionuoja darbuotojų skatinimo ir motyvavimo sistemos. Todèl šio tyrimo tikslas buvo sukurti savo sistemą pagal išsivysčiusių šaliu ekonomikoje taikomas darbuotojų skatinimo metodikas ir aptikti efektyviausius jų komponentus, o tyrimo objektas - organizacinès elgsenos efektyvumo vertinimas, remiantis organizacijos eksperimentiniais tyrimais. Siekiant išsamiai ištirti ši klausimą, buvo atlikta dviejų Gorio (Gruzijos) gamyklų "Kula" ir "Agrocom" darbuotojų apklausa.

Kadangi Gruzija bando rasti veiksmingiausius ir efektyviausius skatinimo ir efektyvinimo metodus ir juos adaptuoti pagal savo šalies galimybes, tai šiuo pereinamuoju laikotarpiu šalyje yra didžiulis darbo vietų trūkumas ir jis lemia žemą dirbančių žmonių užimtumo lygị. Todèl šalis privalo įdiegti naujausias motyvavimo metodikas, taikyti inovacijas, technologijas, skatinančias pokyčius. Mokslo ir technikos pažanga straipsnyje grindžiama aprašytais kintamaisiais, formulemis. Tyrimas parodè, jog tinkamai apmokyti vadovai, jų žinios gali padèti jų vykdomoms funkcijoms ir tokiu būdu galima realizuoti pokyčius organizacijoje, susidoroti su iškilusiomis kliūtimis, nes nacionalinès kultūros skirtumai gali turèti didelès ịtakos organizacijos efektyvumui, o viena patirtis negali būti aklai adaptuota ar pakeista.

Išsivysčiusiose vakarų šalyse veikia daugybė organizacijų valdymo, organizacinès elgsenos ir kitų veiksmingų darbo organizavimo praktikų, tačiau jose turi būti išdèstytos pagrindinès kryptys, tinkančios Gruzijai, nes šioje šalyje vykstantys politiniai, ekonominiai ir socialiniai pokyčiai kuria naują supratimą apie organizacinès elgsenos problemas, o svarbiausia efektyviai sprendžia užimtumo klausimus.

Pagrindiniai žodžiai: organizacinès elgsenos efektyvumo rodiklis, vertinimo kriterijus, parametras, koeficientas, motyvacija, skatinimas, efektyvumas, kvalifikacija, komponentas. 


\section{AUTORIAUS LYDRAŠTIS}

Autoriaus vardas, pavardė Tamar Vanishvili

Mokslo laipsnis ir vardas: Vadybos mokslų daktarè

Darbo vieta ir pareigos: Gruzijos Davido Aghmashenebeli nacionalinės gynybos akademijos Egzaminų centro vyriausioji specialiste

Autoriaus mokslinių interesų sritys: vadyba, lyderystė, organizacijos elgsena, motyvacija, skatinimas

Telefonas ir el. pašto adresas: +995 599-99-67-71;

vanishvilitamuna@gmail.com

\section{AUTHOR'S COVER LETTER}

Author's name and surname: Tamar Vanishvili

Academic degree and name: Academic Doctor of Business Administration

Workplace and position: David Aghmashenebeli National Defense Academy of Georgia, Main Specialist of Exam Centre

Author's research interests: management, leadership, organizational behavior, motivation, stimulation

Telephone and e-mail address: +995 599-99-67-71;

vanishvilitamuna@gmail.com 